Ekonomia - Wroclaw Economic Review 27/1 (2021)

Acta Universitatis Wratislaviensis

No 4066

https://doi.org/10.19195/2658-1310.27.1.4

Katarzyna Pastuszka

University of Glasgow

k.pastuszka@onet.eu

Sławomir Pastuszka

ORCID: 0000-0003-3999-923X

Uniwersytet Jana Kochanowskiego w Kielcach

slawomir.pastuszka@ujk.edu.pl

\title{
COVID-19 w Polsce - sekwencja epidemii według modelu SIR
}

Artykuł nadesłany: 6.01.2021; artykuł zaakceptowany: 28.08.2021

Kody klasyfikacji JEL: A12, C02, C52, C53

Abstract

COVID-19 in Poland - epidemic sequence according to the SIR model

The paper aims to indicate the duration and intensity of the COVID-19 epidemic in Poland. To achieve this goal, the SIR interval model was used. The study was based on data from the Central Statistical Office, Hopkins University, and the Institute of Global Health at the University of Geneva. Based on the analysis results, it was established that the prognosis of the epidemic's course largely depends on the size of the adopted $\mathrm{R}$ virus reproduction coefficient. The higher the coefficient, the more rapid the predicted course of the epidemic, the shorter the duration, and the greater the number of infected. And vice versa: the smaller the coefficient, the milder its course, the longer its duration, and the smaller the number of infected. For this reason, it is important to accurately assess the intensity of the epidemic's development measured by the virus renewal rate, depending on the nature and intensity of interpersonal contacts. Perhaps in a given country different values of the coefficient for urbanized and rural areas should be used.

Słowa kluczowe: SARS-CoV-2 virus, SIR epidemiological model, prognosing

\section{Wstęp}

Choroby zakaźne towarzyszyły ludzkości niemal od samego początku. Dżuma, czarna ospa, tyfus, malaria, hiszpanka dziesiątkowały ludność na całym świecie. 
Obecnie chorobą, która pochłania wiele ofiar, jest COVID-19, wywołana przez wirus SARS-CoV-2. Pierwszy potwierdzony przypadek choroby odnotowano 8 stycznia 2020 roku w Chinach, w Wuhan w prowincji Hubei. Jak wynika z danych Światowej Organizacji Zdrowia, 18 listopada 2020 roku na COVID-19 chorowało ponad $55 \mathrm{mln}$ ludzi z 235 krajów, z których zmarło ponad 1,328 $\mathrm{mln}^{1}$. Jest oczywiste, że po wskazanym terminie sytuacja związana z występowaniem koronawirusa zmieniała się dynamicznie. Każdego dnia na świecie zwiększała się liczba zakażonych oraz ofiar wirusa. Tylko 17 listopada 2020 roku stwierdzono prawie 487 tys. nowych zakażeń i 7,4 tys. zgonów, najwięcej w najludniejszych krajach: w Stanach Zjednoczonych, Brazylii, Indiach i Meksyku. Spośród krajów europejskich najwyższy bilans zgonów z powodu koronawirusa odnotowano w Wielkiej Brytanii (52,1 tys.), Włoszech (45,7 tys.), Francji (44,7 tys.) i Hiszpanii (40,7 tys.). W tym czasie w Polsce zarażonych było 733,8 tys. osób, z czego 10,5 tys. zmarło.

Starając się powstrzymać rozprzestrzenianie wirusa, władze niemal na całym świecie wprowadziły ograniczenia dotyczące przemieszczania się wewnątrz kraju i za granicę, zakazu opuszczania określonych obszarów i nakazu przebywania w innych, a także funkcjonowania przedsiębiorstw i instytucji publicznych. Czasowo zamknięto granice państwowe, wstrzymano lub w znacznym stopniu ograniczono międzynarodowy transport lotniczy i samochodowy. W efekcie wprowadzonych obostrzeń doszło do zakłócenia globalnego łańcucha dostaw towarów i materiałów pośrednich, wiele branż musiało ograniczyć lub wręcz wstrzymać działania $^{2}$. Największe straty przychodów, zwłaszcza w pierwszym etapie pandemii, odnotowały przedsiębiorstwa oferujące usługi transportowe, turystyczne, kulturalno-eventowe, gastronomiczne, hotelarskie, sportowe czy edukacyjne (NBP, 2020).

Nawarstwianie się problemów przedsiębiorstw spowodowało pogorszenie kondycji całej gospodarki światowej. Międzynarodowy Fundusz Walutowy spodziewał się spadku globalnej gospodarki w 2020 roku o 4,9\% (World Economic Outlook Update, 2020), większe spadki światowego PKB szacował Bank Światowy (The World Bank, 2020) -5,2\% i OECD (2020) -6,0\%. Głębszej recesji doświadczyła Europa, pomimo programów stymulacji fiskalnej oraz silnie ekspansywnej polityki pieniężnej banków centralnych ${ }^{3}$. PKB Unii Europejskiej w drugim kwartale 2020 roku w stosunku do analogicznego okresu sprzed roku zmalał o 14,8\%, czyli prawie cztery razy więcej niż w pierwszym kwartale (-3,3\%). Najbardziej skurczyły się gospodarki Wielkiej Brytanii i Hiszpanii (po -21,5\%). Większy spadek dynamiki PKB od średniej wartości tego wskaźnika w UE odnotowały także:

1 WHO Coronavirus Disease (COVID-19) Dashboard. Data dostępu: 19.11.2020, https:// covid19.who.int/table.

${ }^{2}$ Wyjątkiem jest branża IT, zwłaszcza przedsiębiorstwa, które dzięki pracy zdalnej, mogły prowadzić sprzedaż w Internecie, dostarczać usługi wideokonferencyjne.

3 W Polsce rząd na różne formy pomocy w ramach programu Tarcza Antykryzysowa Tarcza Finansowa przeznaczył 212 mld zł, to jest 10\% krajowego PKB. 
Francja (-18,9\%), Włochy (-17,9\%), Portugalia (-16,4\%), Chorwacja, Grecja i Malta (po -15,2\%). W Polsce PKB zmniejszył się o 8,0\%, więcej niż w krajach skandynawskich, nadbałtyckich, Irlandii i Luksemburgu.

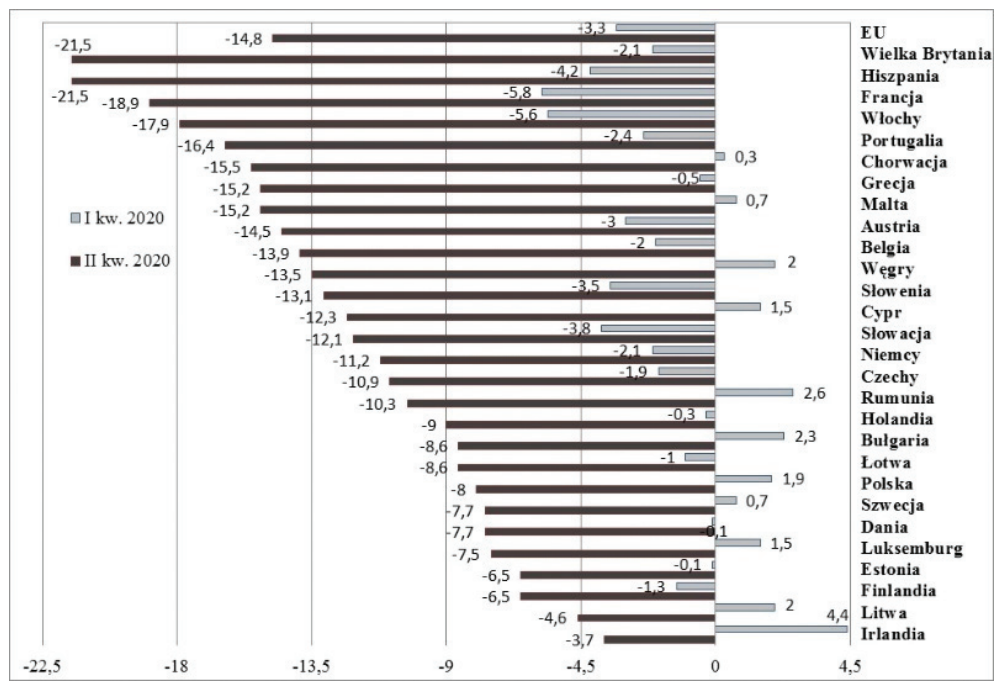

Wykres 1. Wzrost PKB w 2020 roku (zmiana kwartał do kwartału w ujęciu rocznym), w \%

Źródło: Newsrelease. Euroindicators, 168/2020-13.11.2020.

Jak wynika z informacji GUS (2020c), główną przyczyną spadku PKB było znaczne zmniejszenie popytu krajowego oraz nakładów inwestycyjnych przedsiębiorstw (9,5\%). Wyraźnemu pogorszeniu uległa także sytuacja na rynku pracy. W pierwszym półroczu 2020 roku pracę straciło 271 tys. osób, przy czym według szacunków GUS (2020b) w przypadku jednej czwartej zlikwidowanych miejsc pracy przyczyną była pandemia koronawirusa. Charakterystyczne jest, że zmniejszenie liczby pracujących bardziej zbliżone było do skali wzrostu populacji biernych zawodowo, mniej zaś do wzrostu grupy osób bezrobotnych ${ }^{4}$. Zdaniem N. Roubiniego (2020) ostateczne rozmiary strat w gospodarce zależą od skali oraz tempa rozprzestrzeniania się koronawirusa. Pełniejsza analiza tego zjawiska jest przedmiotem prezentowanego opracowania, którego celem jest prognozowanie przebiegu epidemii COVID-19 w Polsce za pomocą modelu SIR.

Główną tezą niniejszego artykułu jest twierdzenie, że model SIR, mimo pewnych ograniczeń, jest bardzo pomocnym narzędziem matematycznym w ocenie przebiegu epidemii. Udowodnienie przyjętej tezy ułatwi uzyskanie odpowiedzi na dwa pytania badawcze:

${ }^{4}$ Według GUS (2020a) zbiorowość bezrobotnych w II kwartale 2020 r. pozostała na zbliżonym poziomie z poprzedniego kwartału. Prawdopodobnie wynika to z tego, że wiele osób, które utraciły pracę, ze względu na zamknięcie szkół, ograniczenie zakresu działalności wielu instytucji czy konieczność zachowania dystansu społecznego nie spełniały warunków BAEL, by zaliczyć ich do grona bezrobotnych (aktywne poszukiwanie pracy i gotowość jej podjęcia). 
— jak długo według prognozy modelu SIR potrwa pandemia od jej wystąpienia?

— jaka według prognozy modelu SIR może być skala zachorowań i kiedy może nastąpić ich szczyt?

Pierwsza część pracy zawiera ogólną charakterystykę modeli epidemii SIR i SEIR. W części drugiej omówiono założenia i strukturę modelu SIR wykorzystanego do analizy rozprzestrzeniania się wirusa SARS-CoV-2 w Polsce. Część trzecia prezentuje przewidywany przebieg epidemii koronawirusa w Polsce według wyników modelu SIR, czwarta — według prognoz krajowych i zagranicznych badaczy, natomiast piąta - według oficjalnych danych Ministerstwa Zdrowia. Opracowanie kończy podsumowanie wcześniejszych rozważań oraz ważniejszych wniosków.

\section{Charakterystyka klasycznych modeli epidemii SIR i SEIR}

Do opisu wielu zjawisk społeczno-gospodarczych wykorzystywane są modele matematyczne. Pozwalają one uchwycić pewne specyficzne cechy i powtarzające się zjawiska, na podstawie których można identyfikować i prognozować ich przebieg w charakterze procesów. Modeli tych, jak stwierdził brytyjski statystyk George E.F. Box (1976), nie można jednak traktować jako narzędzia doskonałego ze względu na dużą złożoność zjawisk społeczno-gospodarczych i mnogość wpływających na nie czynników. Modele zwykle bazują bowiem na pewnych założeniach i kryteriach, ale nie uwzględniają wielu specyficznych okoliczności lub losowych zdarzeń, które mogą mieć wpływ na badane zjawisko, na przykład zachowań ludzi, gęstości ich zamieszkania, mobilności geograficznej, intensywności kontaktów międzyludzkich, polityki władz. Taki złożony charakter ma epidemia koronawirusa SARS-CoV-2. Jej przebieg najczęściej opisywany jest przy pomocy klasycznych przedziałowych modeli epidemiologicznych SIR oraz SEIR (Tadusiewicz, Jaworek, Kańtoch i inni, 2012; Jarynowski, Grabowski, 2015).

Model SIR po raz pierwszy został zastosowany w 1927 roku przez szkockich badaczy, Williama Kermacka i Andersona McKendricka (1927, 700-721), później wykorzystywany był do oceny przebiegu różnych chorób zakaźnych przenoszonych drogą powietrzną (Sattenspiel, Dietz, 1995, 71-91; Arino, Driessche, 2003, 175-193; Ruan, 2007, 99-102). W modelu zakłada się podział badanej grupy (N) na trzy przedziały (subpopulacje):

$$
N=S+I+R
$$

gdzie: S (Susceptible) — osoby zdrowe, które nie mają odporności na infekcję, dlatego są podatne na zakażenie, I (Infective) — osoby zakażone, R (Recovered 
and removed) - osoby ozdrowiałe i zmarke w wyniku przebytej infekcji. W modelu nie uwzględnia się osób przechodzących chorobę bez objawów, zakłada się natomiast, że zainfekowana osoba zaczyna zakażać inne i albo zdrowieje, po pewnym czasie uzyskując całkowitą odporność na infekcję patogenem, albo umiera.

Model SIR zastosowali naukowcy z różnych ośrodków badawczych na świecie, zwracając uwagę na różne charakterystyczne zjawiska w przebiegu epidemii. Uczeni chińscy z Uniwersytetu Medycznego w Tiencin oraz Uniwersytetu Pekińskiego stwierdzili, że rozprzestrzenianie się COVID-19 we wczesnej fazie było porównywalne z przebiegiem epidemii ostrego zespołu oddechowego SARS CoV i znacznie wyższe niż w przypadku MERS-CoV (Huang i in., 2020). Zespół badaczy z Uniwersytetów w Sydney i Essex zaakcentował zagrożenie wykładniczego wzrostu zakażeń koronawirusem w Chinach, Korei Południowej, Indiach, Australii, USA i we Włoszech oraz prawdopodobieństwo osłabienia infekcji dopiero przed osiągnięciem szczytu zakażeń (Cooper, Mondal, Antonopoulos, 2020, 1-14). $\mathrm{W}$ ocenie badaczy warunkiem spowolnienia rozwoju epidemii jest zdecydowane ograniczenie przemieszczania się ludzi i przebywania w miejscach publicznych, aż do całkowitego zamknięcia miast. Tak radykalne działania podjęły tylko władze Chin już w początkach rozwoju epidemii, w innych rejonach świata w tym czasie nie przewidywano tak dużego zagrożenia. W efekcie sprawdziły się przewidywania Milana Batisty (2020) z Uniwersytetu w Lublanie oraz Igora Nesteruka (2020) z Ukraińskiej Akademii Nauk, że spowolnieniu epidemii w Chinach będzie towarzyszył dynamiczny wzrost liczby zakażeń w innych częściach świata. Precyzyjne określenie skali wzrostu zachorowań w ocenie ekspertów (Anastassopoulou i in., 2020) jest niezmiernie trudne ze względu na liczne przypadki łagodnego lub wręcz bezobjawowego przebiegu infekcji COVID-19, szczególnie wśród ludzi młodych.

Obok modelu SIR jest stosowany model SEIR, , w którym oprócz trzech przedziałów populacji SIR (Susceptible-Infectious-Recovered) wyodrębniono czwartą grupę ludzi narażonych (Exposed, E). Jest to grupa osób z chorobą w fazie utajonej, które uległy zakażeniu, ale jeszcze nie zarażają innych ze względu na okres inkubacji patogenu. W modelu SEIR z jednej strony, podobnie jak w modelu SIR, populacja jest stała, nie uwzględnia rozrodczości, śmiertelności i migracji, z drugiej jednak, w odróżnieniu do SIR, zakłada się, że powrót do zdrowia po wirusie nie zapewnia odporności na całe życie, więc osoby wyzdrowiałe mogą ponownie zachorować. Model ten również jest wykorzystywany przez badaczy naukowych (Almeida, 2018; Berger, Herkenhoff, Mongey, 2020; He, Peng, Sun, 2020, 16671680; Wu, Leung, Leung, 2020) do badania rozwoju SARS-CoV-2. Eksperci niezależnie od uzyskanych wyników (różnią się one ze względu na inny zakres geograficzny, przedział czasowy i dane wyjściowe) twierdzą, że epicentrami epidemii są większe ośrodki miejskie połączone z innymi miastami ruchem lotniczym, kolejowym i drogowym — tam właśnie najpilniej powinny zostać wprowadzone największe obostrzenia w codziennym funkcjonowaniu społeczeństwa. Ich zdaniem 
zmniejszenie liczby zakażeń może nastąpić w wyniku częstszego testowania oraz ukierunkowanej polityki kwarantanny.

Spośród zmiennych w modelu SEIR najmniej jednoznaczne wydają się być dane dotyczące odsetka osób narażonych (E), które przechodzą chorobę bez objawów. Z tego względu zdecydowano, żeby analizę sekwencji koronawirusa w Polsce przeprowadzić z wykorzystaniem modelu SIR.

\section{Model SIR — założenia i struktura}

Model SIR charakteryzuje populację w czasie. Zmienną niezależną jest liczony w dniach czas (t), w którym zmieniają się wielkości podgrup $\mathbf{S}, \mathbf{I}, \mathbf{R}$. Jak już wcześniej zaznaczono, liczebność populacji w modelu jest stała w czasie:

$$
N \rightarrow N(t)=S(t)+I(t)+R(t)
$$

i dokładnie wymieszana, co znaczy, że prawdopodobieństwo spotkania innej osoby jest dla każdego jednakowe. Dla uzyskania większej czytelności obliczeń liczba podatnych $(\boldsymbol{S})$, zakażonych $(\boldsymbol{I})$ i ozdrowiałych/zmarłych $(\boldsymbol{R})$ jest podana jako proporcja w stosunku do całej populacji $(\boldsymbol{N})$ :

$$
\begin{aligned}
& s(t)=\frac{S(t)}{N}-\text { udział osób zdrowych, } \\
& i(t)=\frac{I(t)}{N}-\text { to udział osób chorych, } \\
& r(t)=\frac{R(t)}{N}-\text { to udział osób odpornych (ozdrowiałych/zmarłych). }
\end{aligned}
$$

Zmianę liczebności osób w poszczególnych grupach wyznacza się za pomocą trzech równań różniczkowych (Ordinary Differential Equation, ODE) 5 .

1. Wzrost liczby osób podatnych na zakażenie $\rightarrow \frac{d \boldsymbol{S}}{d \boldsymbol{t}}=-\alpha \mathbf{s}(\boldsymbol{t}) \boldsymbol{i}(\boldsymbol{t})$.

Ujemny znak pochodnej oznacza, że liczba osób podatnych (S) maleje, ponieważ z czasem mogą oni zachorować i wtedy znajdą się w grupie zakażonej.

2. Wrost liczby osób zakażonych $\rightarrow \frac{d \boldsymbol{I}}{d \boldsymbol{t}}=\alpha \mathbf{s}(\boldsymbol{t}) \mathbf{i}(\boldsymbol{t})-\boldsymbol{\beta} \mathbf{i}(\boldsymbol{t})$.

Liczba nowo zakażonych osób wzrasta w tempie $a \mathbf{s}(\mathbf{t}) \mathbf{i}(\mathbf{t})$, a osoby już zakażone zostaną usunięte z grupy w tempie $\boldsymbol{\beta} \mathbf{i}(\mathbf{t})$, gdy wyzdrowieją lub umrą.

Wielkość $\alpha$ określa prawdopodobne tempo rozprzestrzeniania się wirusa, tzw. siłę infekcji, a $\boldsymbol{\beta}$ jest współczynnikiem wyzdrowienia, i oznacza tempo, w jakim

5 The SIR Model for Spread of Disease. Data dostępu: 24.11.2020, https://services.math.duke. edu/education/postcalc/sir/sir2.html. 
ludzie wracają do zdrowia po infekcji. Odwrotność $\beta$ oznacza średni czas trwania infekcji (Ciarochi, 12.03.2020).

Wartość parametru $\alpha$ można obliczyć po przekształceniu wzoru $\boldsymbol{R}_{B}=\frac{\mathrm{a} \boldsymbol{s}_{0}}{\boldsymbol{b}}$ na współczynnik reprodukcji infekcji, otrzymując $\boldsymbol{\alpha}=\frac{\boldsymbol{R}_{\boldsymbol{B}} \boldsymbol{b}}{\boldsymbol{s}_{0}}$. Współczynnik ten wskazuje, ile powstaje wtórnych zakażeń z jednego pierwótnego. Jeżeli współczynnik reprodukcji jest wyższy niż 1, to przyjmuje się, że epidemia się rozwija; jeśli zaś spada on poniżej 1, przyjmuje się, że epidemia jest w fazie spadkowej, a koronawirus rozprzestrzenia się wolniej. Wartość współczynnika zależy tak od czynników biologicznych (własności wirusa), jak i społecznych (gęstość populacji, obyczaje, częstość podroży), toteż niełatwo ją ustalić (Kleczkowski, 2020).

W początkowej fazie epidemii są tylko osoby podatne i zakażone, nie ma jeszcze żadnych wyleczonych ani zmarłych, więc wielkości przedstawiają się następująco:

$$
\boldsymbol{S} \mathbf{0}=\mathrm{S}_{\mathbf{0}}>0, \quad \text { I } 0=I_{0}>\mathbf{0}, \quad \mathbf{R} \mathbf{0}=\boldsymbol{R}_{\mathbf{0}}=\mathbf{0}, \text { oraz } \boldsymbol{S}_{\mathbf{0}}+\boldsymbol{I}_{\mathbf{0}}=\boldsymbol{N} .
$$

3. Wrrost liczby osób odzyskanych, czyli wyleczonych lub/i zmarlych $\rightarrow \frac{\boldsymbol{d} \boldsymbol{R}}{\boldsymbol{d} \boldsymbol{t}}=\boldsymbol{\beta} \boldsymbol{\boldsymbol { B }}(\boldsymbol{t})$.

Dodatni znak pochodnej oznacza, że liczba osób odzyskanych (R) wzrasta.

Suma wszystkich trzech pochodnych z powyższych równań wynosi zero.

$$
\begin{gathered}
\frac{d s}{d t}+\frac{d i}{d t}+\frac{d r}{d t}=-\alpha s(t) i(t)+(\alpha s(t) i(t)-\beta i(t))+\beta i(t)=0 \\
\frac{d}{d t}(s+i+r)=\frac{d N}{d t}=0
\end{gathered}
$$

\section{Sekwencja COVID-19 w Polsce - wyniki analizy wg modelu SIR}

Do przeprowadzenia analizy wykorzystano dane:

- o liczbie ludności w Polsce $(N)$, publikowane przez Główny Urząd Statystyczny (stan na koniec stycznia 2020 roku) ${ }^{6}$,

- o liczbie osób zakażonych koronawirusem $\left(\boldsymbol{I}_{\mathbf{0}}\right)$, publikowane przez Uniwersytet Johna Hopkinsa (stan na 11 marca 2020 roku),

${ }^{6}$ Baza Demografia - Główny Urząd Statystyczny. Data dostępu: 25.11.2020, http://demografia.stat.gov.pl/bazademografia/Tables.aspx.

7 W tym dniu nie odnotowano żadnego przypadku ozdrowienia ani zgonu z powodu COVID-19 ( $\mathrm{R}=0$ ), co stanowi założenie modelu SIR. COVID-19 Dashboard by the Center for Systems Science and Engineering (CSSE) at Johns Hopkins University (JHU). Data dostępu: 25.11.2020, https://coronavirus.jhu.edu/map.html. 
— wartość bazową wskaźnika reprodukcji wirusa $\left(\boldsymbol{R}_{\boldsymbol{B}}\right)^{8}$, publikowaną przez Instytut Globalnego Zdrowia Uniwersytetu Genewskiego (stan na 16 marca 2020 roku $)^{9}$.

Do stworzenia modelu SIR dla COVID-19 w Polsce użyto następujących zmiennych:

— całkowitą populację w Polsce $N=38379000$,

- liczbę $I_{0}$ i udział osób $i_{0}$ zakażonych koronawirusem

$$
\boldsymbol{i}_{\mathbf{0}}=\frac{\mathbf{I}_{0}}{\mathbf{N}}=8,07733 \times 10^{-7} \approx 8,077 \times 10^{-7},
$$

— liczbę $\left(\boldsymbol{I}_{\mathbf{0}}\right)$ i udział osób podatnych na zarażenie $\boldsymbol{S}_{\mathbf{0}}$ :

$\boldsymbol{S}_{\mathbf{0}}=38378969 \boldsymbol{s}_{\mathbf{0}}=\frac{\boldsymbol{S}_{\mathbf{0}}}{\boldsymbol{N}}=\frac{38378969}{38379000}=0,9999991923$,

- liczbę $\boldsymbol{R}_{\mathbf{0}}$ i udział ( $\left.\boldsymbol{r}_{\mathbf{0}}\right)$ osób wyzdrowiałych i zmarłych $\boldsymbol{R}_{\mathbf{0}}=\mathbf{0}$ i $\boldsymbol{r}_{\mathbf{0}}=\mathbf{0}$,

— wskaźnik reprodukcji $\boldsymbol{R}_{\boldsymbol{B}}=1,92$ (pierwszy scenariusz) i 1,6 (drugi scenariusz),

- czas leczenia COVID-19 zwykle trwa około $14 \mathrm{dni}\left(\frac{\mathbf{1}}{\boldsymbol{b}}=14\right)$, dlatego parametr $\boldsymbol{b}=0,071429 \approx 0,0714$,

— parametr $\alpha=0,13994$, ponieważ, $\boldsymbol{R}_{\boldsymbol{B}}=1,92=\frac{\mathrm{a} \times 0,9999991923}{0,071429}$, to $\boldsymbol{\alpha}=\frac{1,92 \times 0,071429}{0,9999991923}=0,14$.

Wartość $\alpha$ w pierwszym wariancie, przy $\boldsymbol{R}_{\boldsymbol{B}}=1,92$, posłużyła do wyznaczenia przebiegu trzech trajektorii, zilustrowanych na wykresie 2 :

1. przyrostu liczby osób podatnych na zakażenie $\frac{d s}{d t}=-0,14 \times s(t) i(t)$,

2. przyrostu liczby osób zakażonych $\frac{d i}{d t}=0,14 \times s(t) i(t)-0,0714 \times i(t)$,

3. przyrostu liczby osób odzyskanych $\frac{d r}{d t}=0,1714 \times i(t)$.

${ }^{8}$ Na samym początku epidemii współczynnik odnowienia wirusa R w Polsce został ustalony na wysokim poziomie 1,92. Po wprowadzeniu działań mających na celu ograniczanie rozprzestrzeniania się wirusa (Ustawa z dnia 2 marca 2020 roku o szczególnych rozwiązaniach związanych z zapobieganiem, przeciwdziałaniem i zwalczaniem COVID-19, innych chorób zakaźnych oraz wywołanych nimi sytuacji kryzysowych), 22 marca 2020 roku uznano za uzasadnione zmniejszenie tego współczynnika do 1,6, a 31 marca 2020 roku — do 1,3. Stąd też autorzy niniejszego artykułu zdecydowali się na przedstawienie dwóch scenariuszy przebiegu pandemii: z uwzględnieniem współczynnika R według stanu na 16 marca (I scenariusz) i 22 marca 2020 roku (II scenariusz).

9 COVID-19 Daily Epidemic Forecasting. Powered by the Institute of Global Health, Faculty of Medicine, University of Geneva and the Swiss Data Science Center, ETH Zürich-EPFL. Data dostępu: 25.11.2020, https://renkulab.shinyapps.io/COVID-19-Epidemic-Forecasting/. 


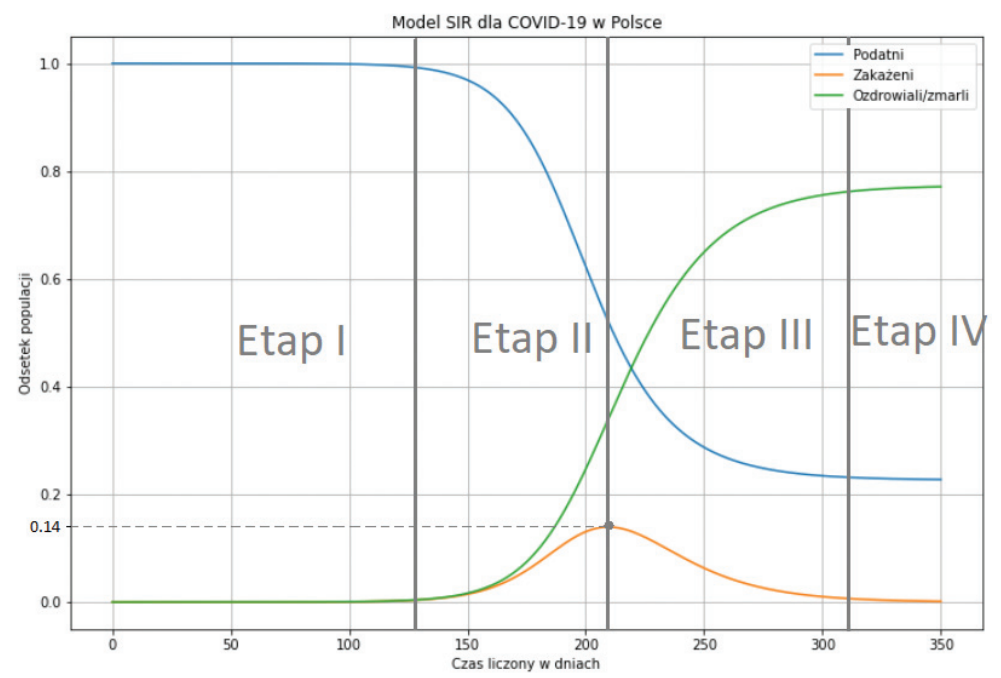

Wykres 2. Symulacja epidemii COVID-19 w Polsce wg modelu SIR dla $R_{B}=1.92$

Źródło: opracowanie własne przy wykorzystaniu programu Jupyter Notebook (Anaconda 3).

$\mathrm{Z}$ zaprezentowanej na powyższym wykresie graficznej formy uzyskanych wyników można wysnuć wniosek, że w sugerowanym przez model SIR przebiegu epidemii COVID-19 w Polsce da się wyodrębnić cztery etapy. W pierwszym etapie epidemia miała mieć łagodny przebieg przez około 130 dni od daty jej wystąpienia (3 marca 2020 roku). W drugim etapie tempo wzrostu nowych zakażeń miało wyraźnie wzrastać do około 210. dnia epidemii (wrzesień) i osiągnięcia szczytu zachorowań przy maksymalnej wartości w przybliżeniu 0,14 na osi y, co odpowiada $14 \%$ całkowitej populacji (około 5,35 miliona). W trzecim etapie dynamika rozprzestrzeniania się wirusa miała się stopniowo obniżać do 310. dnia epidemii, co obrazuje ujemne nachylenie funkcji zakażonych i dodatnie nachylenie funkcji wzrostu liczby odzyskanych (R). W ostatnim etapie krzywa zachorowań miała ulec wypłaszczeniu aż do wygaśnięcia epidemii po około 340 dniach jej trwania, kiedy liczba zakażonych spadłaby do zera, a liczba podatnych (ok. $23 \%$ populacji) oraz ozdrowiałych i zmarłych (około $77 \%$ populacji) osiągnie stan równowagi.

Pokazana na wykresie maksymalna przybliżona liczba zakażonych została precyzyjnie obliczona z wykorzystaniem następującego równania:

$$
i_{\text {max }}=1-\rho \ln \left(s_{0}\right)-\rho+\rho \ln \rho=1-\rho+\rho \ln \frac{\rho}{s_{0}}
$$

gdzie $\rho=\frac{b}{a}$ : to względny współczynnik usuwania zakażonych osób z populacji ogółem

$$
i_{\max }=1-\rho+\rho \ln \frac{\rho}{s_{0}}=1-0,510+0,510 \times \ln \left(\frac{0,510}{0,9999991923}\right)=0,139414661
$$




$$
i_{\text {max }}=\frac{I_{\text {max }}}{N}=0,1394, \quad I_{\max }=0,1394 \times 38279000=5350595
$$

W drugim scenariuszu przebiegu epidemii, przy $R_{B}=1.6$, przebieg trzech analizowanych trajektorii został przedstawiony na wykresie 3 . Wynika z niego łagodniejszy przebieg epidemii. Wyraźny wzrost liczby zakażeń powinien rozpocząć się później, po 190. dniach epidemii, a nie po 130, jak w pierwszym scenariuszu. Podobnie później powinno nastąpić apogeum pandemii, po około 305 dniach jej trwania, a nie 210, jak w pierwszym scenariuszu. Maksymalna liczba osób zakażonych powinna stanowić około 8,5\% populacji (118 tys. osób), a nie $14 \%$, jak w pierwszym scenariuszu. W kolejnych miesiącach tempo zachorowań powinno powoli spadać do ich wygaśnięcia, jednak wyraźnie w dłuższym okresie - po 480 dniach jej trwania, a nie 340, jak w pierwszym scenariuszu. W tym wariancie stan równowagi wystąpiłby przy udziale w całości populacji $35 \%$ osób podatnych i $65 \%$ osób ozdrowiałych i zmarłych (w pierwszym scenariuszu odpowiednio: $23 \%$ i $77 \%$ ).

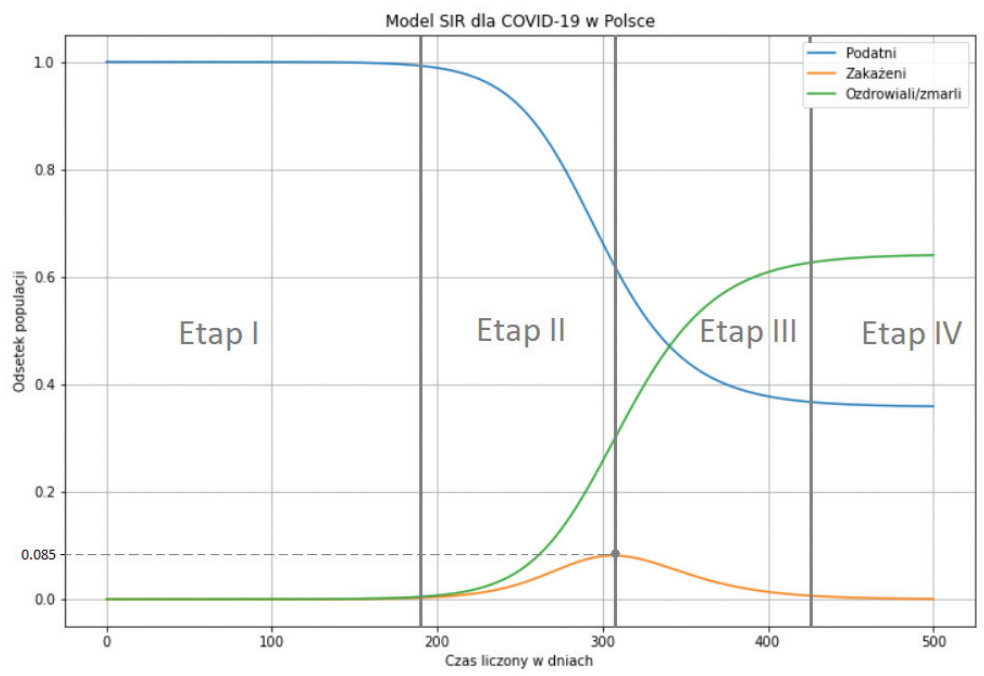

Wykres 3. Symulacja epidemii COVID-19 w Polsce wg modelu SIR dla $\left(R_{B}\right)=1,6$ Źródło: opracowanie własne przy wykorzystaniu programu Jupyter Notebook (Anaconda 3). 


\section{Sekwencja COVID-19 w Polsce - wyniki badań krajowych i zagranicznych}

Sytuacja epidemiczna w Polsce jest przedmiotem analiz krajowych i zagranicznych ekspertów. Na bieżąco uaktualniają prognozy w miarę rejestrowania nowych danych i daje się zauważyć skracanie okresu czasu predykcji nawet do kilku dni.

Naukowcy z Wydziału Matematyki, Informatyki i Mechaniki Uniwersytetu Warszawskiego (MIMUW) oraz Narodowego Instytutu Zdrowia Publicznego Państwowego Zakład Higieny (NIZP PZH) na 25 maja 2020 roku przewidywali 24 tys. zakażeń (przyrost dzienny zakażeń został zilustrowany na wykresie 4 krzywą koloru czerwonego $)^{10}$. Jednocześnie wskazali na wzrastającą liczbę przypadków niezdiagnozowanych (na wykresie ilustruje je niebieska krzywa wraz z przedziałem ufności oznaczonym kolorem jasnoniebieskim).

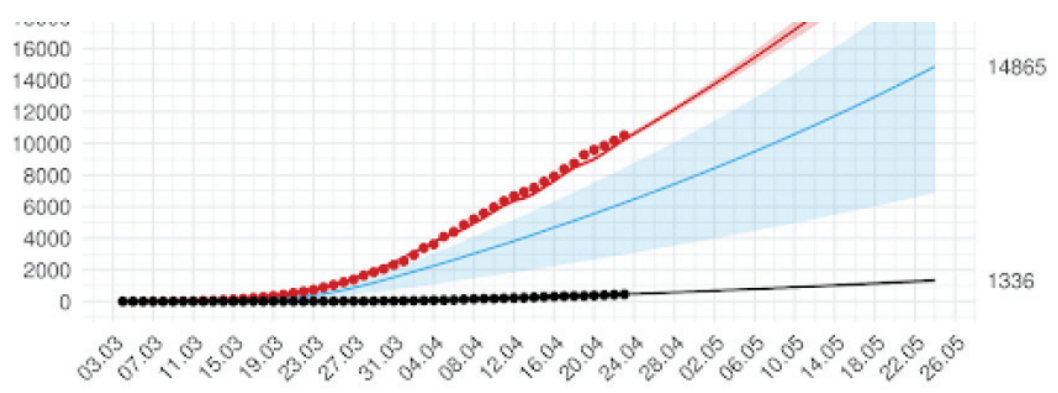

Wykres 4. Przebieg epidemii COVID-19 w Polsce według prognozy MIMUW i NIZP PZH (stan na 25.05.2020)

Źródło: Modele dotyczące COVID-19 przygotowywane przez naukowców z UW. Data dostępu: 25.11.2020, https://www.uw.edu.pl/modele-dotyczace-covid-19-przygotowywane-przez-naukowcow-z-uw/.

W dniu 28 sierpnia 2020 roku eksperci szacowali, że na początku września liczba nowych zakażeń może przekroczyć 1000 przypadków dziennie, a od początku października - osiągnie prawie 1,5 tys. przypadków. W prognozie z 18 listopada 2020 roku przewidywali że, jeśli dynamika zakażeń nie ulegnie zmianie, ich liczba wzrośnie 24 listopada do ponad 868 tys., a liczba zgonów - 13,2 tys. Przewidzieli też wyraźny wzrost przypadków niezdiagnozowanych do prawie 4,781 tys. $^{11}$

10 Modele dotyczące COVID-19 przygotowywane przez naukowców z UW. Data dostępu: 25.11.2020, https://www.uw.edu.pl/modele-dotyczace-covid-19-przygotowywane-przez-naukowcow-z-uw/.

11 Modelowanie COVID-19. Data dostępu: 25.11.2020, https://covid19.mimuw.edu.pl/. 


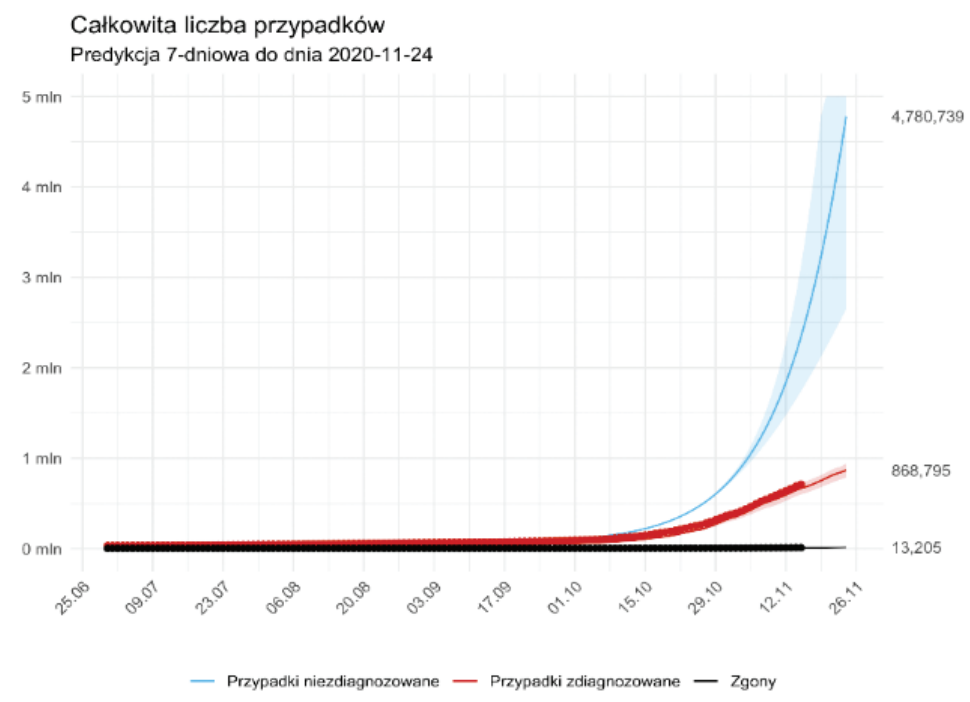

Wykres 5. Przebieg epidemii COVID-19 w Polsce według modelu MIMUW i NIZP PZH (stan na 18.11.2020)

Źródło: Model STOCH-SEIR. Data dostępu: 25.11.2020, https://covid19.mimuw.edu.pl/.

Na problem niewykrytych przypadków koronawirusa zwrócili uwagę także eksperci Interdyscyplinarnego Centrum Modelowania Matematycznego i Komputerowego ${ }^{12}$. Według ich symulacji z 9 listopada 2020 roku około połowa populacji ulegnie zakażaniu, liczba zdiagnozowanych i nieudokumentowanych przypadków infekcji będzie około dziewięć razy większa niż stwierdzonych. Prognozowali, że maksimum epidemii wystąpi na początku grudnia 2020 roku; później powinien nastąpić spadek (wykres 6).

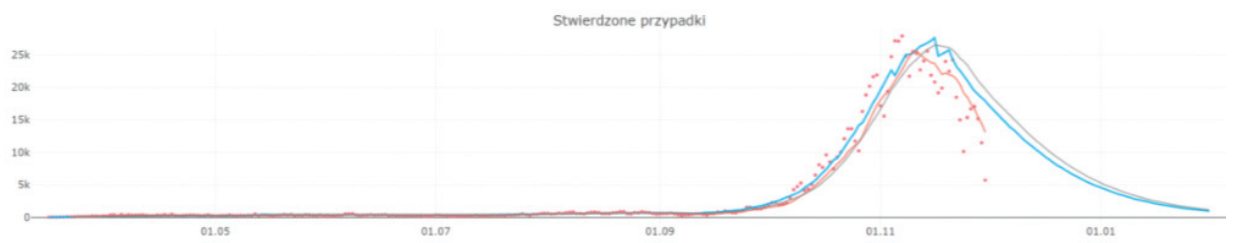

Wykres 6. Przebieg zakażeń w Polsce wg modelu ICM UW (stan na 9.11.2020)

Źródło: Model Epidemiologiczny ICM. Data dostępu: 26.11.2020, https://covid-19.icm.edu.pl/biezace-prognozy/.

12 Model Epidemiologiczny ICM. Data dostępu: 25.11.2020, https://covid-19.icm.edu.pl/biezace-prognozy/. 
Mając świadomość ograniczonej wiarygodności danych gromadzonych w systemie ewidencji osób zakażonych, eksperci Imperial College London oraz Centrum Analiz Epidemiologicznych i modelowania chorób zakaźnych (MRC Centre for Global Infectious Disease Analysis) rozwój wirusa COVID-19 analizują głównie na podstawie zgonów ${ }^{13}$. W prognozie z 24 sierpnia 2020 roku przewidywali, że liczba ofiar śmiertelnych koronawirusa powinna się wahać od kilku do kilkunastu dziennie, w symulacji z połowy listopada, że może wzrosnąć do ponad 500 zgonów. Jednocześnie szacowali, że współczynnik odnowienia wirusa będzie oscylować wokół wartości 1, a co za tym idzie, przewidywano stałą w czasie liczbę zachorowań.

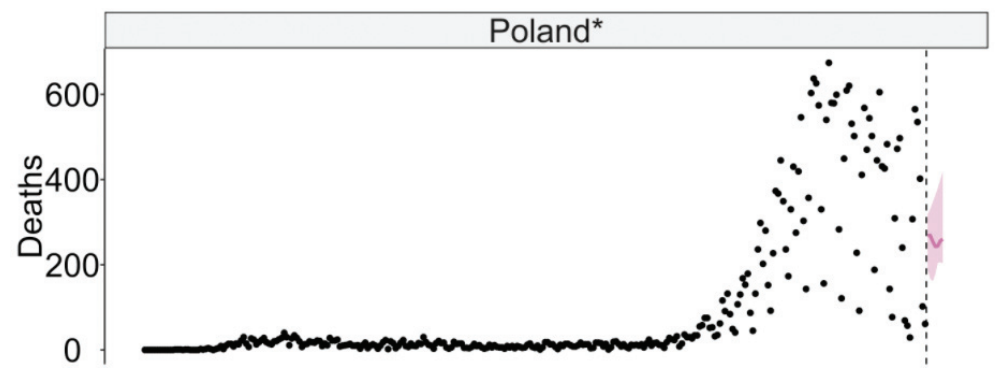

Wykres 7. Prognoza zgonów z powodu COVID-19 w Polsce wg modelu ICL MRC GIDA (stan na 15.11.2020)

Źródło: Short-term forecasts of COVID-19 deaths in multiple countries. Data dostępu: 26.11.2020, https://mrc-ide.github.io/covid19-short-term-forecasts/index.html.

Umiarkowane tempo rozprzestrzeniania się koronawirusa w Polsce prognozowali także eksperci szwajcarscy z Uniwersytetu Genewskiego, Politechniki Federalnej w Zurychu i Swiss Data Science Center ${ }^{14}$. Zgodnie z ich przewidywaniami współczynnik reprodukcji wirusa od kwietnia do sierpnia 2020 roku miał utrzymywać się na poziomie zbliżonym do 1, co oznacza, że jedna zakażona osoba miała zarażać średnio jedną zdrową osobę. Od sierpnia do października 2020 roku szwajcarscy badacze prognozowali wzrost wartości tego współczynnika do poziomu 1,59, a następnie spadek do $0,96 \mathrm{w}$ drugiej połowie grudnia 2020 roku (wykres 8), co oznaczałoby, że epidemia powinna wygasać.

13 Short-term forecasts of COVID-19 deaths in multiple countries. Data dostępu: 26.11.2020, https://mrc-ide.github.io/covid19-short-term-forecasts/index.html.

14 COVID-19 Daily Epidemic Forecasting. 


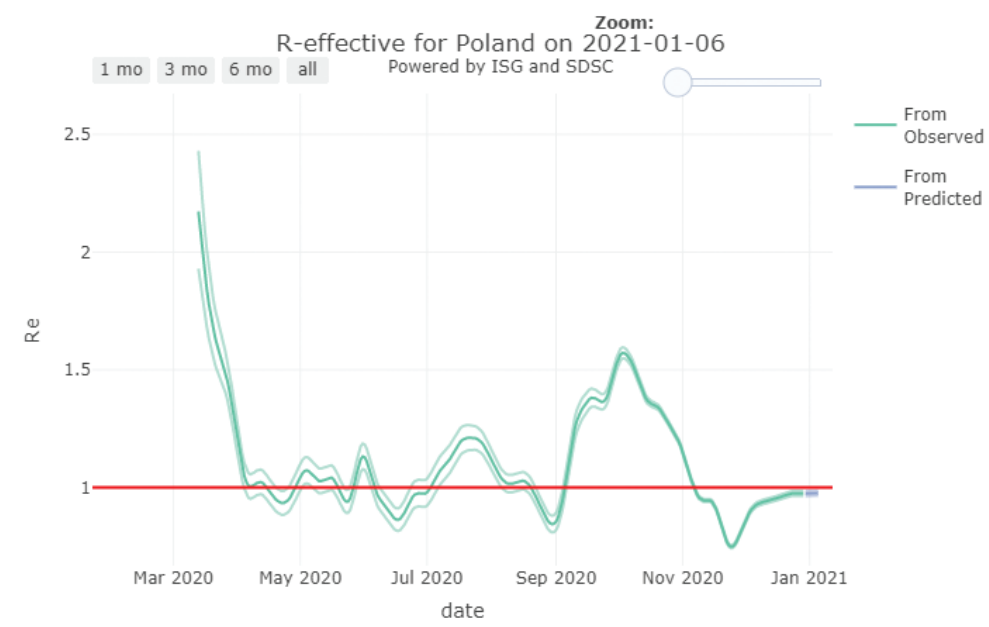

Wykres 8. Wskaźnik odnowienia wirusa R w Polsce wg modelu IGH SDSC (stan na 6.01.2021)

Źródło: COVID-19 Daily Epidemic Forecasting. Data dostępu: 6.01.2020, https://renkulab.shinyapps. io/COVID-19-Epidemic-Forecasting/_w_d9b24c94/_w_aae54a43/?tab=ecdc_pred\&country=Poland.

\section{Przebieg COVID-19 w Polsce według oficjalnych danych}

Dane dotyczące przebiegu epidemii COVID-19 w Polsce są podawane przez Ministerstwo Zdrowia ${ }^{15}$. Te wartości, dotyczące Polski i wielu innych krajów, są także systematycznie gromadzone i udostępniane przez Europejskie Centrum do spraw Zapobiegania i Kontroli Chorób (ECDC) ${ }^{16}$. Informacje te obejmują tylko osoby, u których stwierdzono wirusa COVID-19 na podstawie pozytywnego wyniku testu. Dlatego liczba faktycznie zakażonych osób prawdopodobnie jest o wiele większa od liczby oficjalnie potwierdzonych przypadków, zwłaszcza w krajach, w których testami obejmuje się mniejszy odsetek ogólnej liczby mieszkańców ${ }^{17}$.

15 Do 23 listopada 2020 roku przedstawiano liczbę zakażeń i zgonów w ujęciu dziennym i narastająco. Po tym dniu te wielkości są podawane tylko w raportach dziennych. Zob. Raport zakażeń koronawirusem (SARS-CoV-2). Data dostępu: 26.11.2020, https://www.gov.pl/web/koronawirus/wykaz-zarazen-koronawirusem-sars-cov-2.

16 European Centre for Disease Prevention and Control. An Agency of the European Union. Data dostępu: 26.11.2020, https://www.ecdc.europa.eu/en/publications-data/download-todays-data-geographic-distribution-covid-19-cases-worldwide.

17 Zakażenie COVID-19 przeszło prawdopodobnie około 11\% Polaków. Data dostępu: 26.11.2020, https://www.onet.pl/informacje/onetwiadomosci/koronawirus-w-polsce-ilu-polakowmialo-covid-19/71m5b9b,79cfc278. 
Rozbieżność może także wynikać z powodu niewykrytych albo niezgłoszonych infekcji, szczególnie u osób przechodzących chorobę łagodnie lub bezobjawowo, błędów w badaniach laboratoryjnych, braku zintegrowanego i spójnego systemu raportowania o zakażeniach (Kuropaś, 2020; Frątczak, 2020; Molga, 2020; Rogalski, 2020). Zatem ze świadomością ograniczonej wiarygodności tych danych, poddano je analizie. Na jej podstawie wyodrębniono trzy główne fazy przebiegu zakażeń COVID-19 w Polsce ${ }^{18}$. W pierwszej fazie, trwającej około $100 \mathrm{dni}$, stwierdzone zachorowania utrzymywały się na stosunkowo niskim poziomie 28,5 tys. $\mathrm{W}$ drugiej fazie, przez kolejne $114 \mathrm{dni}$, tempo rozprzestrzeniania się koronawirusa uległo wyraźnemu przyspieszeniu, osiągając łącznie ponad 100 tys. zakażeń. Po tym okresie można wyodrębnić trzecią fazę, w której odnotowano skokowy przyrost stwierdzonych zachorowań aż do poziomu 876,3 tys. osób w 264. dniu epidemii, to jest 23 listopada 2020 roku. Najwyższą dobową liczbę nowych infekcji $-27,9$ tys., odnotowano 8 listopada. Od tego dnia dynamika zachorowań wprawdzie stopniowo malała, ale ogólna liczba osób zakażonych nadal wzrastała. Trudno zatem oczekiwać, że sprawdzą się prognozy wygaśnięcia epidemii w Polsce, wykazane zarówno w pierwszym, jak i w drugim scenariuszu modelu SIR.

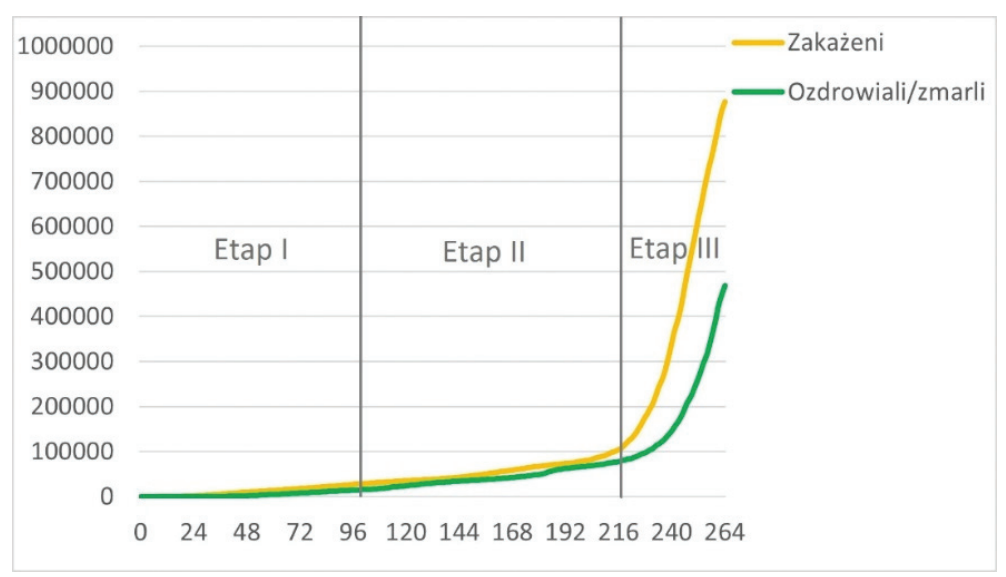

Wykres 9. Liczba osób zakażonych oraz ozdrowiałych i zmarłych w Polsce do 264. dnia epidemii

Źródło: opracowanie własne na podstawie oficjalnych danych Ministerstwa Zdrowia. Data dostępu: 6.12.2020, https://www.gov.pl/web/koronawirus/wykaz-zarazen-koronawirusem-sars-cov-2.

18 Podobny podział na etapy zakażenia koronawirusem zaproponował Aleksander Polański w analizie Prognoza rozwoju epidemii COVID-19 w Polsce. Data dostępu: 5.12.2020, https://www. researchgate.net/publication/339987615_Prognoza_rozwoju_epidemii_koronawirusa_COVID19_w_Polsce. 


\section{Zakończenie}

Przeprowadzona analiza pozwoliła na sformułowanie kilku wniosków.

- Model SIR umożliwił rozpoznanie probabilistycznego przebiegu epidemii COVID-19 w Polsce i wyodrębnienie jej kolejnych etapów: niewielkiego wzrostu zakażeń, następnie wyraźnego przyspieszenia aż do osiągnięcia szczytu, a w dalszej kolejności stopniowego obniżania dynamiki zachorowań i zmniejszenia się liczby chorych do zera. Czas i dynamika przebiegu etapów zależy w dużym stopniu od przyjętego współczynnika reprodukcji wirusa. Przy większych wartościach epidemia ma przebieg bardziej gwałtowny, krótszy okres trwania i większą liczbę zakażonych. I odwrotnie: przy mniejszym współczynniku epidemia przebiega łagodniej, wydłuża się okres jej trwania, a zmniejsza liczba zakażonych.

- Między prognozowaną w obu scenariuszach modelu SIR liczbą zakażonych a wielkościami podawanymi przez resort zdrowia występują wyraźne różnice. Po części może to wynikać z niedoskonałości modelu, a po części z niepełnej wiarygodności oficjalnych danych statystycznych dotyczących prawdopodobnie niedoszacowanej liczby zakażeń i wpływu epidemii na liczbę zgonów. Obiektywność oficjalnych danych o liczbie zakażeń poddali w wątpliwość naukowcy Interdyscyplinarnego Centrum Modelowania Uniwersytetu Warszawskiego. Szacowali ją na około dziewięć razy mniejszą od liczby niezdiagnozowanych i nieudokumentowanych przypadków infekcji. Ten problem dostrzegli także eksperci brytyjscy, koncentrując się w prognozach epidemii przede wszystkim na informacjach o liczbie zgonów.

- Oficjalne dane na temat przebiegu epidemii COVID-19 w Polsce, nawet mimo ich ograniczonej wiarygodności wskazują, że w pierwszych sześciu miesiącach trwania epidemii władze prawdopodobnie w niewielkim stopniu korzystały z możliwego wsparcia procesu decyzyjnego modelami matematycznymi. Zastosowane w okresie wiosennym 2020 roku rygorystyczne obostrzenia i wywołana nimi dyscyplina społeczna miały korzystny wpływ na ograniczenie dynamiki zachorowań w kolejnych miesiącach. Prawdopodobnie wywołało to u decydentów politycznych przekonanie, że udało się skutecznie zapanować nad przebiegiem epidemii. Władze zdecydowały się wtedy na zliberalizowanie wcześniejszych obostrzeń, co przyczyniło się do wzrostu intensywności kontaktów ludzkich, w szczególności związanych z odpoczynkiem wakacyjnym, rozpoczęciem roku szkolnego, organizacją imprez sportowych, spotkań towarzyskich, okolicznościowych i religijnych. W efekcie faktyczna liczba chorych rozsiewających zakażenia zamiast się zmniejszać, jak wykazano w obu scenariuszach modelu SIR, zaczęła wręcz gwałtownie wzrastać.

- Wyniki przedstawionego badania potwierdzają sformułowaną tezę, że model SIR nie jest idealnym narzędziem do precyzyjnego określenia sekwencji epidemii, nie uwzględnia bowiem różnych czynników, które mogą mieć wpływ na 
jej rzeczywisty przebieg, na przykład gęstości zaludnienia, natężenia mobilności geograficznej ludzi, intensywności kontaktów międzyludzkich, ogólnej kondycji zdrowotnej społeczeństwa, efektywności systemu opieki zdrowotnej, wprowadzanych przez władze restrykcji ukierunkowanych na zapobieganie zakażeniu i zwalczanie wirusa oraz stopnia ich przestrzegania przez społeczeństwo. Mimo naturalnych ograniczeń, model SIR, jak każdy inny model matematyczny, powinien być traktowany jako przydatne narzędzie w rozpoznaniu ogólnych tendencji rozwoju chorób zakaźnych i w podejmowaniu decyzji na rzecz ograniczenia rozprzestrzeniania się epidemii.

\section{Bibliografia}

Almeida, R. (2018). Analysis of fractional SEIR model with treatment, Applied Mathematics Letters, 84. Data dostępu: 22.11.2020, https://www.researchgate.net/publication/324520191_Analysis_of_a_fractional_SEIR_model_with_treatment.

Anastassopoulou, C., Russo, L., Tsakris, A., Siettos, C. (2020). Data-based analysis, modelling and forecasting of the COVID-19 outbreak. PLOS ONE, 15 (3).

Arino, J., Driessche, P. van den. (2003). A multi-city epidemic model. Mathematical Population Studies, 10 (3), 175-193.

Berger, D., Herkenhoff, K., Mongey, S. (2020). An SEIR infectious disease model with testing and conditional quarantine. NBER Working Paper, nr 26901.

Box, G.E.P. (1976). Science and statistics. Journal of the American Statistical Association, 71 (356), 791-799.

Cooper, I., Mondal, A., Antonopoulos, C.G. (2020). A SIR model assumption for the spread of COVID-19 in different communities. Chaos, Solitons \& Fractals, 139, 1-14.

Frątczak, N. (24.11.2020). Sanepid zgubił 22 tys. przypadków zakażenia koronawirusem. Połowa z nich jest na Mazowszu. Gazeta Wyborcza.

GUS. (2020a). Informacja o rynku pracy $w$ drugim kwartale 2020 r. (dane wstęne).

GUS. (2020b). Wptyw epidemii COVID-19 na wybrane elementy rynku pracy w Polsce w I kwartale $2020 \mathrm{r}$.

GUS. (2020c). Wstępny szacunek produktu krajowego brutto w II kwartale 2020 r. Informacje sygnalne.

Ciarochi, J. (12.03.2020). How COVID-19 and other infectious diseases spread: mathematical modeling. Data dostępu: 24.11.2020, https://triplebyte.com/blog/modeling-infectious-diseases.

He, S., Peng, Y., Sun, K. (2020). SEIR modeling of the COVID-19 and its dynamics. Nonlinear Dynamics, 101, 1667-1680. Data dostępu: 24.11.2020, https://doi.org/10.1007/s11071-020-05743-y.

Huang, Y., Yang, L., Dai, H., Tian, F., Chen, K. (16.03.2020). Epidemic situation and forecasting of COVID-19 in and outside China. Data dostępu: 22.11.2020, https://www.who.int/bulletin/ online_first/20-255158.pdf.

Jarynowski, A., Grabowski, A. (2015). Modelowanie epidemiologiczne dedykowane w Polsce, Centrum Zastosowań Matematyki.

Kermack, W.O., McKendrick, A.G. (1927). A contribution to the mathematical theory of epidemics. Proceedings of The Royal Society, ser. A, 115 (772), 700-721.

Kleczkowski, A. (2020). Matematyka i wirusy. PAUza Akademicka, 509-510.

Kuropaś, D. (19.11.2020). Wątpliwości dotyczące raportowania: czy dobrze liczymy testy i zakażenia koronawirusem? Rynekzdrowia.pl. Data dostępu: 4.12.2020, https://www.rynekzdrowia.

Ekonomia. Wroclaw Economic Review 27/1 (2021)

(C) for this edition by CNS 
pl/Polityka-zdrowotna/Watpliwosci-dotyczace-raportowania-czy-dobrze-liczymy-testy-i-zakazenia-koronawirusem,215368,14.html.

NBP. (2020). Szybki Monitoring NBP — analiza sektora przedsiębiorstw (styczeń 2020).

Molga, T. (24.11.2020). Koronawirus. Bałagan w sanepidzie zmienit statystyki. Ujawniono ,zgubione" przypadki. Data dostępu: 5.12.2020, https://wiadomosci.wp.pl/koronawirus-balagan-w-sanepidzie-uratowal-nas-przed-lockdownem-ujawniono-zgubione-przypadki$-6579060563712864 a$.

Newsrelease. Euroindicators, 168/2020-13.11.2020.

OECD Economic Outlook. (2020). The world economy on a tightrope. Data dostępu: 20.11.2020, https://www.oecd.org/economic-outlook/.

Polański, A. (2020). Prognoza rozwoju epidemii COVID-19 w Polsce. Data dostępu: 5.12.2020, https://www.researchgate.net/publication/339987615_Prognoza_rozwoju_epidemii_koronawirusa_COVID-19_w_Polsce.

Rogalski, M. (15.12.2020). Michat Rogalski dla Gazeta.pl: Jak oficjalne dane o epidemii w Polsce stracily swoja wiarygodność. Data dostępu: 5.12.2020, https://next.gazeta.pl/ next/7,173953,26578403,michal-rogalski-dla-gazeta-pl-jak-oficjalne-dane-o-epidemii. html\#s=BoxMMt1.

Roubini, N. (6.04.2020). This is what the economic fallout from coronavirus could look like. World Economic Forum. Data dostępu: 21.11.2020, https://www.weforum.org/agenda/2020/04/depression-global-economy-coronavirus/.

Ruan, S. (2007). Spatial-temporal dynamics in nonlocal epidemiological models. Y. Takeuchi, K. Sato, Y. Iwasa (eds.), Mathematics for life science and medicine. Berlin: SpringerVerlag.

Sattenspiel, L., Dietz, K. (1995). A structured epidemic model incorporating geographic mobility among regions. Mathematical Biosciences, 128 (1-2), 71-91.

Short-term forecasts of COVID-19 deaths in multiple countries. Data dostępu: https://mrc-ide.github.io/covid19-short-term-forecasts/index.html.

The SIR model for spread of disease. Data dostępu: 24.11.2020, https://services.math.duke.edu/ education/postcalc/sir/sir2.html.

Tadusiewicz, R., Jaworek, J., Kańtoch, E., Miller, J., Pięciak, T., Przybyło, J. (2012). Wprowadzenie do modelowania systemów biologicznych oraz ich symulacji w środowisku MATLAB. Lublin: Uniwersytet Marii Curie-Skłodowskiej.

Ustawa z dnia 2 marca 2020 roku o szczególnych rozwiązaniach związanych z zapobieganiem, przeciwdziałaniem i zwalczaniem COVID-19, innych chorób zakaźnych oraz wywołanych nimi sytuacji kryzysowych, Dz.U. 2020, poz. 374.

The World Bank. (8.06.2020). The global economic outlook during the COVID-19 pandemic: A changed world. https://www.worldbank.org/en/news/feature/2020/06/08/the-global-economic-outlook-during-the-covid-19-pandemic-a-changed-world.

World Economic Outlook. (2020). A crisis like no other, an uncertain recovery. https://www.imf. org/en/Publications/WEO/Issues/2020/06/24/WEOUpdateJune2020.

Wu., J., Leung, K., Leung, G.M. (31.01.2020). Nowcasting and forecasting the potential domestic and international spread of the 2019-nCoV outbreak originating in Wuhan, China: A modelling study. The Lancet. Data dostępu: 24.11.2020, https://www.thelancet.com/journals/lancet/ article/PIIS0140-6736(20)30260-9/fulltext.

\section{Źródła internetowe}

Baza Demografia — Główny Urząd Statystyczny. Data dostępu: 24.11.2020, http://demografia.stat. gov.pl/bazademografia/Tables.aspx. 
COVID-19 Daily Epidemic Forecasting. Powered by the Institute of Global Health, Faculty of Medicine, University of Geneva and the Swiss Data Science Center, ETH Zürich-EPFL. Data dostępu: 25.11.2020, https://renkulab.shinyapps.io/COVID-19-Epidemic-Forecasting/.

COVID-19 dashboard by the Center for Systems Science and Engineering (CSSE) at Johns Hopkins University (JHU). Data dostępu: 25.11.2020, https://coronavirus.jhu.edu/map.html.

European Centre for Disease Prevention and Control. An Agency of the European Union. https:// www.ecdc.europa.eu/en/publications-data/download-todays-data-geographic-distribution-covid-19-cases-worldwide.

Model Epidemiologiczny ICM. Data dostępu: 25.11.2020, https://covid-19.icm.edu.pl/biezace-prognozy/.

Modele dotyczące COVID-19 przygotowywane przez naukowców z UW. Data dostępu: 26.11.2020, https://www.uw.edu.pl/modele-dotyczace-covid-19-przygotowywane-przez-naukowcow-z-uw/.

Modelowanie COVID-19. Data dostępu: 25.11.2020, https://covid19.mimuw.edu.pl/.

Raport zakażeń koronawirusem (SARS-CoV-2). Data dostępu: 26.11.2020, https://www.gov.pl/web/ koronawirus/wykaz-zarazen-koronawirusem-sars-cov-2.

World Health Organization. Coronavirus Disease (COVID-19) Dashboard. Data dostępu: 19.11.2020, https://covid19.who.int/table.

Zakażenie COVID-19 przeszło prawdopodobnie ok. 11 proc. Polaków. Data dostępu: 26.11.2020, https://www.onet.pl/informacje/onetwiadomosci/koronawirus-w-polsce-ilu-polakow-mialo-covid-19/71m5b9b,79cfc278. 